University of Pennsylvania Carey Law School

Penn Law: Legal Scholarship Repository

Faculty Scholarship at Penn Law

$4-11-2007$

\title{
First Generation E-Rulemaking: An Assessment of Regulatory Agency Websites
}

\author{
Stuart Shapiro \\ Rutgers University \\ Cary Coglianese \\ University of Pennsylvania Carey Law School
}

Follow this and additional works at: https://scholarship.law.upenn.edu/faculty_scholarship

Part of the Administrative Law Commons, Communication Technology and New Media Commons, Organizational Communication Commons, and the Science and Technology Law Commons

\section{Repository Citation}

Shapiro, Stuart and Coglianese, Cary, "First Generation E-Rulemaking: An Assessment of Regulatory Agency Websites" (2007). Faculty Scholarship at Penn Law. 147.

https://scholarship.law.upenn.edu/faculty_scholarship/147

This Article is brought to you for free and open access by Penn Law: Legal Scholarship Repository. It has been accepted for inclusion in Faculty Scholarship at Penn Law by an authorized administrator of Penn Law: Legal Scholarship Repository. For more information, please contact PennlawIR@law.upenn.edu. 


\section{First Generation E-Rulemaking: An Assessment of Regulatory Agency Websites}

\author{
Stuart Shapiro \\ Rutgers University \\ Edward J. Bloustein School \\ 33 Livingston Ave \#274 \\ New Brunswick, NJ 08901 \\ 1-732-932-2499 ext 870 \\ stuartsh@ rci.rutgers.edu
}

\author{
Cary Coglianese \\ University of Pennsylvania Law School \\ 3400 Chestnut Street \\ Philadelphia, PA 19104 \\ 1-215-898-6867 Telephone \\ cary_coglianese@law.upenn.edu
}

\begin{abstract}
We examine 89 websites from federal regulatory agencies in order to evaluate their ease of use for those interested in commenting on or learning about their proposed regulations. We find that while there has been a lot of attention given to second and third generation "e-rulemaking” efforts, agency websites, a first generation innovation, still have considerable room for improvement. Notwithstanding legislative and executive branch efforts to enhance the accessibility of regulatory information on the Internet, our coding of regulatory agency websites reveals considerable variation in the quality of agency websites, with many websites still failing to provide relatively basic features.
\end{abstract}

\section{Categories and Subject Descriptors}

H.3.5 [Information Storage and Retrieval]: Online Information Services - web-based services, K.4.1 [Computers and Society]: Public Policy Issues - regulation

\section{General Terms}

Management, Design, Legal Aspects.

\section{Keywords}

e-rulemaking, websites, regulation.

\section{INTRODUCTION}

Most digital government research on regulation focuses on what might be considered "second generation" e-rulemaking - that is, on new initiatives and bold ideas about using technology to make the regulatory process more transparent and citizen-centered [2, 3, 8, 9, 11]. These initiatives and ideas include the recent creation of a one-stop portal called Regulations.Gov, the on-going development of a government-wide on-line regulatory docket management system, and the early stages of developing language processing tools to read and sort public comments [4, 7]. Some researchers contemplate even more innovative applications of technology in the future that will enable citizens to engage in interactive deliberations about new rules [10] and to analyze their specific regulatory obligations more easily [6].

Accepted for presentation at the 8th Annual International Digital Government Research Conference, 2007, Philadelphia, PA.
As attractive as any second, and even third, generation innovation will inevitably be, researchers would do well not to overlook what can be learned from the first generation of e-rulemaking, namely the agency website. Since the 1990s, regulatory agencies have made rulemaking information available at their websites. Several statutes have sought to encourage agencies to make their records available on these sites, and evolving practice seems to have made the website a nearly ubiquitous prerequisite for nearly any major institution, public or private. ${ }^{1}$ Since agency websites have been around longer than any other form of e-rulemaking, taking a closer look at regulatory information on the web can shed some light on the diffusion and implementation of digital technologies in government, perhaps even providing a hint of what is realistic to expect from second and subsequent generations of erulemaking.

Academics have debated the impact e-rulemaking will have on public participation and governmental decision-making, with some trumpeting revolutionary changes from advanced information technology [5], and others suggesting that information technology is unlikely to change much of anything at all $[1,12]$. As with scholars, government decision makers too have had their debates. One of the principal points of contention over the current implementation of the Federal Docket Management System, for example, has been whether erulemaking should be centralized and made uniform, or whether different agencies should be permitted to create and administer their own separate on-line docket systems. Despite both scholarly and administrative debates, little has been learned about what agencies have already done to make their rulemaking processes more accessible via their websites. This gap in the digital government literature is all the more striking since, even with the advent of Regulations.Gov, presumably many citizens who wish

\footnotetext{
1 As early as 1996, in the Clinger-Cohen Act, Congress directed the Office of Management and Budget to "promote and be responsible for improving the acquisition, use, and disposal of information technology by the Federal Government to improve ... dissemination of public information.” The E-Government Act of 2002 sought to "increase access, accountability, and transparency" through "a publicly accessible Federal Government website includes all [required] information about that agency."
} 
to participate in particular rulemakings still visit the website of the agency proposing the new rule.

Analysis of regulatory information on agency websites is therefore overdue. While others have examined government websites more generally $[13,14]$, the aim of this study has been to assess systematically the availability and ease of access to regulatory information on government websites. We attempt to answer the following questions.

- Are agency regulatory websites adequate to serve the goal of better public access to the regulatory process?

- Which agency websites provide the easiest access to regulatory information?

- $\quad$ Can we predict which agencies will have better websites using such factors as agency size or agency regulatory activity?

To answer these questions, we collected data on the websites of 89 federal agencies that were the most frequent issuers of new regulations during 2003-2005. We collected our data on a single day in November 2005, before any agency dockets were migrated to the new Federal Docket Management System housed at Regulations.Gov.

In the following section, we explain our choices of which basic data to collect. Then in Section II, we discuss previous studies on agency websites and describe our data collection process. In Section III, we report our results. In Section IV we discuss the results. Finally, we consider the implications of our findings for both academic research and policy debates over e-rulemaking.

\section{EVALUATING REGULATORY INFORMATION ON AGENCY WEBSITES}

To evaluate an agency's regulatory website, we attempted to put ourselves in the place of a member of the public who wanted to better understand or comment on an agency rulemaking. In order to participate in agency rulemaking via the Internet, such a member of the public would have to:

- $\quad$ find the agency website

- $\quad$ understand the agency website

- find general rulemaking information on the agency website

- $\quad$ find the particular rule they were interested in

With these tasks in mind, we collected information in three broad categories. The first category assessed the ease of finding the agency's website, either by typing in the agency name or its acronym directly into a URL (e.g., www.osha.gov) or into Google.

The second category included general information about the agency website. This information was intended to measure the ease of accessibility of the website and included the following data elements:

- Is there a search engine on the agency website? Presumably members of the public interested in commenting on a rule would use a search engine to look for the rule they are interested in.
- Is there a site index or site map on the agency home page? This is another way users could look for information about rules.

- Does the agency home page have a help function, an ask-a-question feature, or otherwise allow users to provide feedback? Users may use these features if they cannot find what they are looking for - or even to provide public comment on regulatory issues.

- Does the website have text only features, other language options, or disability friendly features? Will nontraditional users be able to get information?

The third category included information that, to our knowledge, has never previously been collected, namely data on the electronic availability and access to agency information about rulemaking. To choose the data elements in this category we relied upon our own expertise in the regulatory process. We chose phrases and words related to the regulatory process and asked our data collectors whether these phrases and words were located on the agency home page or whether placing the words into a search engine on the agency home page led users to an agency's rulemaking docket. Agencies keep all supporting materials related to each rulemaking in a designated docket. If users can find the agency's rulemaking docket, they presumably should be able to gather information needed to learn about or comment on a particular rulemaking.

The phrases that we asked coders to find on each agency home page were as follows:

- “Federal Register” -- Proposed and final rules are published in the Federal Register, an official daily "newspaper" of the executive branch.

- “Code of Federal Regulations" -- All existing rules are published in this subject-matter organized code.

- "Regulations.gov" -- This is a government-wide website providing access to information on regulations.

- “Information Quality Act” -- This Act allows the public to challenge agency information supporting new regulations.

- "Freedom of Information Act" -- This Act allows individuals to request information from the government.

- Any of the following words that members of the public might use if they were looking for information about a proposed regulation:
- rule
- rulemaking
- legislation
- regulation
- statute
- $\quad$ standard
- comment
- law
- docket
- $\quad$ proposed rules

- Finally, we asked our coders if they could find any mention of specific proposed rules on agency home pages. 
In addition, we asked coders to type the following words into the search engine on the home page (if any) to see if the coder could find a regulatory docket: rule, regulation, standard, and docket. We asked our coders also to try and find a rulemaking docket on the sitemap (if one existed). If none of the above steps led the coder to a rulemaking docket, we asked the coders to spend two additional minutes trying on their own to find a docket. By using the agency home page, search engine, sitemap, and the ingenuity of well-informed graduate students, we were exhausting the possible options a typical member of the public would likely use in trying to find rulemaking information.

As already noted, we collected data from the websites of 89 federal regulatory agencies. Since one of our purposes was to measure the ability for the public to access information from regulatory agencies on the web, we did not use websites to identify our pool of regulatory agencies. Instead, we compiled data on agency rulemaking from the Federal Register's publication of the semiannual regulatory agenda. Twice each year, each federal agency is required to publish an agenda listing pending and recently completed rulemakings. We included in our study every federal regulatory agency that completed more than two rules per cycle during the preceding five issues of the regulatory agenda.

\section{AGENCY WEBSITES AND COLLECTION OF DATA}

Once the agencies were chosen, we assembled a team of graduate students to collect the data. The initial coding protocol was reached between the authors and then a team of graduate students was assembled. Students coded websites in a university computer lab, so they and the authors could all be in the same room on the same day, helping to ensure that the websites were all evaluated under the same circumstances. After instructions, which included a presentation of a sample coding of one agency website (the EPA), the student coders proceeded each to collect data on two websites -- the Department of Transportation and the Federal Communications Commission - in order to establish intercoder reliability (.88). ${ }^{2} \quad$ Out of 39 data elements collected for each website, only one student differed from the majority 7 times $^{3}$ and no other student differed more than 4 times.

Several other scholars have examined government websites (but not regulatory websites). West examined websites from federal (including executive, legislative, and judicial agencies), state and local governments [14]. He found significant variation, but concluded that in general "many government websites are not offering much in the way of online services" [14]. Stowers, several years earlier found it common for government websites to contain search engines and the ability to contact an agency - but less common to provide access to the disabled [13]. Both Stowers and West also ranked federal agency websites.

\footnotetext{
${ }^{2}$ In addition, one of the authors also duplicated the work of each of the other students on one additional website, providing further confirmation of high intercoder reliability.

${ }^{3}$ This occurred on one of the two websites.
}

\section{RESULTS}

We discuss our results in three parts. We focus first on characteristics of agency websites, then turn to an initial attempt to explain variation in these characteristics and finally to an effort to use these characteristics to rank different agencies' websites.

\subsection{Finding Agency Websites and Regulatory Information on Agency Websites}

The data reveal that most agency websites are easy to find, but that the access to regulatory information on them varies widely. Coders succeeded in easily finding most agency websites. Seventy-five of the 89 agencies were listed on FirstGov, and 87 of the 89 could be found by typing the full name of the agency into Google. ${ }^{4}$ Users who use just the agency's acronym still have a good chance of getting to the agency website. Seventy-five of the 89 agencies could be found simply by typing the acronym into Google, and 54 agencies have a URL that is formed directly from the agency's acronym.

In contrast, the news is more mixed in terms of the usability of the agency websites. On the positive side, eighty-five of the websites have a search engine on their home page. In addition, 69 websites offer a mechanism for users to provide feedback to the agency, and 64 have a help or "ask a question" feature. However, only 33 websites (37\%) gave users the option of accessing the website in a language besides English and only four sites had "disability friendly features." 5

When turning specifically to the access to regulatory information, our research shows a comparative lack of availability of regulatory information on the agencies' home pages. This is noteworthy given that we deliberately selected 89 agencies that had engaged recently in rulemakings. With the exception of the "Freedom of Information Act" and the words "rule," "rulemaking," "regulation" or "standard," none of the terms we coded for appeared on more than half of the home pages. Many appeared on significantly fewer than half. Table 1 shows how often certain terms related to regulation appear with a link on the agency home page.

Rulemaking dockets were not easy to locate on many agency websites. Fifty agencies (56\%) had no link to a docket on their home page. For the other 39 agencies, one of the links on the home page takes a user to some type of docket (31 of those with links to the words "rule," "rulemaking," "regulation," or "standard," and 8 of those with a link to the word "docket"). A docket could be found on the agency's sitemap on only three websites. Our use of the agency search engines allowed us to find only an additional two agencies with central dockets. For those agencies where we still had not found a rulemaking docket, we asked our coders to use their own ingenuity for two minutes to try to find a central rulemaking docket. This resulted in an additional seven agency websites with dockets.

\footnotetext{
${ }^{4}$ Both of the exceptions were within the Department of Defense, the Office of the Assistant Secretary for Health Affairs, and the Defense Acquisitions Regulations Council. For agency names, we used the names as listed in the semiannual regulatory agenda.

${ }^{5}$ Only an additional 9 websites had text-only options.
} 
The sum total of all of these techniques: 51 out of 89 sites (57\%) have a rulemaking docket that a user can readily find. Ten years after the Clinger-Cohen Act, and five years after the EGovernment Act, the federal government is still only part way to mastering one of the simplest possibilities to use the Internet to improve governance.

Table 1. Frequency of Links from Agency Home Pages

\begin{tabular}{|l|c|}
\hline Word or Phrase & $\begin{array}{c}\text { \% Agencies with } \\
\text { Home page Link }\end{array}$ \\
\hline Code of Federal Regulations & $7 \%$ \\
\hline Federal Register & $10 \%$ \\
\hline www.regulations.gov & $27 \%$ \\
\hline Information Quality Act & $18 \%$ \\
\hline Freedom of Information Act & $79 \%$ \\
\hline $\begin{array}{l}\text { The words “rule,” "rulemaking,” } \\
\text { "regulation,” or “standard” }\end{array}$ & $67 \%$ \\
\hline $\begin{array}{l}\text { The words "law,” “legislation,” } \\
\text { "standard” }\end{array}$ & $31 \%$ \\
\hline The word “comment” & $15 \%$ \\
\hline The phrase “Proposed Rules” & $15 \%$ \\
\hline The word “docket” & $10 \%$ \\
\hline
\end{tabular}

\subsection{Exploring Variation in Regulatory Agency Websites}

Although our findings reveal considerable variation in regulatory agency websites, perhaps these results can be explained by the fact that some agencies spend more time issuing more rules, or are simply larger agencies with more resources to devote to information technology. Agencies that regulate more frequently might be expected to invest more to ensure that citizens and interested organizations will be able to use the Internet to gather information about or comment on rules. Posting information in an accessible manner on the Internet may well reduce the amount of time agency personnel need to respond to requests for information, something that may be a greater benefit for agencies that issue more rules.

Even though our dataset included the 89 agencies that regulated the most frequently, there was still considerable variation in rulemaking action within our dataset. We partitioned our data into two groups. The first group consisted of the 21 agencies that had the most frequent pattern of rulemaking, more than an average of 28 new rules per year. The second group consisted of the 68 agencies with a lower level of rulemaking.

Agencies that regulated most frequently did have websites that were slightly easier to find than the remainder of the agencies. Twenty of the 21 frequent regulators could be found on firstgov.gov (as opposed to 55 of the other 68), and 18 of the 21 could be found by typing "www.", followed by the acronym, followed by ".gov" (as opposed to 36 of the other 68).

There were not many differences, though, in the overall general characteristics of their websites. As Table 2 shows, agencies that regulate most frequently were better about allowing users to offer feedback and making the website available in other languages, but were poorer about having a sitemap, text only options, and help features.

Table 2. Characteristics of General Agency Websites, Sorted by Level of Agency Activity

\begin{tabular}{|l|c|c|}
\hline Characteristic & \multicolumn{1}{|c|}{$\begin{array}{c}\text { Most } \\
\text { Frequent } \\
\text { Regulators }\end{array}$} & $\begin{array}{c}\text { Less } \\
\text { Frequent } \\
\text { Regulators }\end{array}$ \\
\hline $\begin{array}{l}\text { Search Engine on Home } \\
\text { Page }\end{array}$ & $20 / 21$ & $65 / 68$ \\
\hline $\begin{array}{l}\text { Link to Sitemap on } \\
\text { Home Page }\end{array}$ & $11 / 21$ & $46 / 68$ \\
\hline Text Only Option & $1 / 21$ & $8 / 68$ \\
\hline Help/Ask a Question & $13 / 21$ & $51 / 68$ \\
\hline $\begin{array}{l}\text { User Can Offer } \\
\text { Feedback }\end{array}$ & $18 / 21$ & $51 / 68$ \\
\hline Other Language Features & $11 / 21$ & $22 / 68$ \\
\hline
\end{tabular}

Presumably we would be most likely to observe a difference in the access to rulemaking information between agencies that regulate most frequently and other agencies. As Table 3 shows, there is no major difference between the most frequent regulators and less frequent regulators in terms of the regulatory links from their home pages. For some terms, agencies that regulate less frequently actually have more regulatory links. A similar pattern is observed for the ability to find a central rulemaking docket.

Among the 21 "most frequent regulators" were ten cabinet departments. We hypothesized that one of the reason that we saw little difference between agencies that regulate frequently and those that do not was that cabinet departments might not be as likely to have websites set up for rulemaking as do the agencies that actually promulgate the rules. However, upon examining the data further, we discovered that while departments were slightly less likely to have the phrases in Table 3 on their websites, this was not enough to explain the lack of difference between most frequent and less frequent regulators.

We also attempted to determine whether agency size was a good explanatory variable for agency website capacity. Agencies with more resources may be more likely to develop "better" websites. For 46 agencies in our sample, we were able to obtain reliable data on the number of employees as a measure of agency size. ${ }^{6}$ As with the frequency of regulation, agency size appears to make little difference in explaining the variation in the quality of agency regulatory websites. ${ }^{7}$ In the general website category, it

6 These data were available for each of the cabinet departments and independent agencies in our sample and all of the agencies in the Departments of Transportation and Agriculture. Data were not available for many subagencies within larger departments.

7 The 18 agencies with more than 10,000 employees were considered "large." The agencies with fewer than 10,000 employees were considered "small." This is an admittedly 
was easier to find the website of large agencies by typing their acronym into a URL, and larger agencies were slightly more likely to make their websites available in an alternative language. In terms of regulatory links, small agencies were actually more likely to have a section on proposed rules, to hyperlink the words "rules" and "regulations" on their home pages, and to provide a link to a central rulemaking docket. These were the only meaningful differences between large agencies and small ones.

Table 3. Frequency of Links to Regulatory Information on Agency Home pages

\begin{tabular}{|l|c|c|}
\hline Word or Phrase & $\begin{array}{c}\text { Most } \\
\text { Frequent } \\
\text { Regulators }\end{array}$ & $\begin{array}{c}\text { Less } \\
\text { Frequent } \\
\text { Regulators }\end{array}$ \\
\hline Code of Federal Regulations & $0 / 21$ & $6 / 68$ \\
\hline Federal Register & $1 / 21$ & $8 / 68$ \\
\hline www.regulations.gov & $5 / 21$ & $19 / 68$ \\
\hline Information Quality Act & $4 / 21$ & $12 / 68$ \\
\hline Freedom of Information Act & $19 / 21$ & $51 / 68$ \\
\hline $\begin{array}{l}\text { The words “rule,” "rulemaking,” } \\
\text { "regulation,” or "standard” }\end{array}$ & $13 / 21$ & $47 / 68$ \\
\hline $\begin{array}{l}\text { The words “law,” “legislation,” } \\
\text { "standard” }\end{array}$ & $4 / 21$ & $24 / 68$ \\
\hline The word “comment” & $1 / 21$ & $12 / 68$ \\
\hline The phrase “Proposed Rules” & $3 / 21$ & $10 / 68$ \\
\hline The word “docket” & $3 / 21$ & $6 / 68$ \\
\hline
\end{tabular}

\subsection{Ranking Agency Websites}

To create a basis for subsequent research to compare website development over time, we created three different index scores for each of the 89 agencies. The first score refers to the general agency website characteristics and the ease of finding the website. The maximum score was a 10 , with one point for each affirmative code. ${ }^{8}$ The second score measures the regulatory content on the agency's website. Again, one point was assigned for each affirmative code; since these questions had multiple parts; theoretically the highest possible score was a 21 . No agency came close to receiving this score. The Food and Drug Administration and the Commodity Futures Trading Corporation each received a 15, and the Occupational Safety and Health

arbitrary cutoff, but it does ensue that 12 of the 14 cabinet departments are in the large category as well as the Environmental Protection Agency.

8 The only agency to receive a nine was the Social Security Administration. Nine agencies received an eight: the Federal Deposit Insurance Corporation, the Small Business Administration, the Food and Drug Administration, the National Aeronautics and Space Administration, the Federal Communications Commission, and the Departments of Housing and Urban Development, Veterans Affairs, Interior, and Agriculture.
Administration received a 14. The third score is merely the sum of the first two scores, with a maximum of 31 . Table 4 shows the agencies with the top total scores.

Both Stowers [13] and West [14] also ranked federal agency websites, though they included all agency websites while we examined only agencies that issued regulations. Stowers' rankings date to 2002; she examined 148 agency websites using some criteria similar to those we used. ${ }^{9}$ While there were no overlaps between her list of the top 12 websites and those with the highest total scores under our calculations, four of the 8 sites on her top 12 which we also examined received at least a 7 out of 10 in the general agency website category. The general website score more closely tracks the qualities Stowers used to rank agencies. Four agencies that ranked highly in her study in 2002 continue to do so in our study (Departments of Agriculture, Treasury, Veterans Affairs, and the Small Business Administration).

Table 4. Overall Ranking of Regulatory Agency Websites

\begin{tabular}{|l|c|c|c|}
\hline Agency & $\begin{array}{c}\text { General } \\
\text { Website } \\
\text { Score }\end{array}$ & $\begin{array}{c}\text { Regulatory } \\
\text { Score }\end{array}$ & $\begin{array}{c}\text { Total } \\
\text { Score }\end{array}$ \\
\hline FDA & 8 & 15 & 23 \\
\hline CFTC & 6 & 15 & 21 \\
\hline $\begin{array}{l}\text { Alcohol \& Tobacco } \\
\text { Tax \& Trade Bureau }\end{array}$ & 7 & 13 & 20 \\
\hline OSHA & 5 & 14 & 19 \\
\hline Fed. Maritime Comm. & 6 & 12 & 18 \\
\hline EPA & 6 & 11 & 17 \\
\hline $\begin{array}{l}\text { Emp. Benefits Security } \\
\text { Administration }\end{array}$ & 6 & 11 & 17 \\
\hline $\begin{array}{l}\text { Comptroller of the } \\
\text { Currency }\end{array}$ & 6 & 11 & 17 \\
\hline Department of Labor & 7 & 10 & 17 \\
\hline NRC & 6 & 10 & 16 \\
\hline FCC & 8 & 8 & 16 \\
\hline SSA & 7 & 16 \\
\hline
\end{tabular}

West conducted a general survey of government websites in 2005, though earlier in the year than we did. He examined a total of 61 federal websites. ${ }^{10}$ Of the websites he ranked as the twelve best,

9 Stowers' sample included "all federal websites of executive agencies (cabinet departments and agencies with their own domain names and independent agencies) plus major legislative and judicial websites with their own domain names" [13]

${ }^{10}$ West's criteria for inclusion are "portal or gateway sites as well as those developed by court offices, legislatures, elected officials, major departments and state or federal agencies service crucial functions of government such as health, human services, taxation, education, corrections, economic developments, administration, natural resources, transportation, elections, and agriculture” [14]. 
ten were also in our sample, 8 of which received at least a score of 7 out of 10 in terms of general agency website characteristics in our study. ${ }^{11}$

\section{DISCUSSION AND CONCLUSIONS}

We have reported initial findings from a comprehensive study of regulatory agency websites. These websites represent the "first generation" of e-rulemaking and yet they have, until now, escaped much systematic investigation. We began our analysis by identifying agencies that engage in rulemaking, and then we proceeded to see whether they had websites that could be easily located, possessed desirable general characteristics, and included accessible information about regulation. Although others have examined federal agency websites, ours is the first study to focus specifically on regulatory agencies and to code for the presence of rulemaking information.

Our data lead us to two sets of observations. The first observation involves the quality of agency websites and the second draws upon our inability to observe an explanation for the variation in this quality.

First, in contrast with all the attention being paid to centralized dockets and innovative comment analysis tools, the first generation of e-rulemaking appears to have been neglected -- not only by scholars, but also by agencies themselves. For example, we found only 1 website for the most frequent rulemaking agencies (out of 21) contained the word "comment" on its home page. Yet adding a button or link telling users how to comment on proposed rules must surely be among the easiest possible steps to take to advance the goal of increasing citizen access to and involvement in the regulatory process. Similarly, we discovered to our surprise the crude functionality of the search engines built into most agency websites. Adding Google search engines on agency home pages would, we suspect, make a significant improvement in the accessibility of agency information, again without presumably much effort or cost.

Yet steps such as these have so far been missed opportunities for making it easier for citizens to participate in rulemaking, steps overlooked by both government managers and scholars who have been devoted their attention to the potential of second generation efforts. To be sure, such second-generation efforts deserve careful attention and consideration; we have ourselves focused on them [4]. Our suggestion would be that, at the same time scholars and government managers justifiably focus on new tools, some thought also be given to standards or best practices for the accessibility of regulatory information on the first generation tool, the worldwide web.

Second, we believe we can learn more about the implementation of digital government projects by seeking to understand why regulatory agencies' websites vary as they do. We have made some initial, so far unsuccessful efforts to this end. Understanding better what explains the variation in the first generation of e-rulemaking may help answer questions relevant to the proper design of the second and third generations of erulemaking.

\footnotetext{
11 The eight agencies are: the Departments of State, Agriculture, Treasury, Housing and Urban Development, and Labor and the FCC, SSA, and Consumer Product Safety Commission.
}

Centralization versus decentralization, for example, has been a key issue for the design of the federal docket management system. Does the variation in the regulatory features of agency websites make it more or less attractive to devolve the design of docket systems to individual agencies? On the one hand, some might find that our data undermine confidence in the ability or willingness of individual agencies on their own to deploy information technology at a consistently high level of quality. If indeed there is no consistent pattern according to which larger or busier agencies produce better websites, then perhaps decentralization leaves the development of important new information technologies too much up to chance. This could lead to an argument for centralization of further electronic rulemaking efforts such as the Federal Docket Management System.

On the other hand, one possible advantage of a devolutionary approach is that it may foster innovations that can later be copied by others. From this perspective, the variation we observe may simply be the byproduct of a healthy system of experimentation and learning. If over time, all agencies improve their website quality, then perhaps decentralization is positive. Of course, modifying a website is much easier than modifying an entire docket management system. Nevertheless, future replication of our study could help determine whether desirable features in agency websites diffuse and whether decentralization, at least in first generation tool design, results in improvement over time. Agency website variation over time is an important area for further research.

\section{ACKNOWLEDGMENTS}

The National Science Foundation's Digital Government Research Program, under award EIA-0226053, supported the development of this project. We appreciate research assistance by Jennifer Nash and Gopal Raman, as well as data collection assistance by our team of coders. Our thanks to anonymous reviewers for their helpful comments.

\section{REFERENCES}

[1] Balla, Steven J. \& Benjamin M. Daniels, Information Technology and Public Commenting on Agency Regulations, Regulation \& Governance 1: 46-67.

[2] Brandon, Barbara H. \& Robert D. Carlitz, 2003. On-line Rulemaking and Other Tools for Strengthening Our Civic Infrastructure, Administrative Law Review 54: 1421.

[3] Coglianese, Cary. 2004. E-Rulemaking: Information Technology and the Regulatory Process, Administrative Law Review 56: 353.

[4] Coglianese, Cary, Stuart Shapiro, and Steven Balla. Unifying Rulemaking Information: Recommendations for the New Federal Docket Management System” Administrative Law Review 57:621 (2005).

[5] Johnson, Stephen. M. 1998. The Internet Changes Everything: Revolutionizing Public Participation and Access to Government Information through the Internet, Administrative Law Review 50:277.

[6] Lau, Gloria T., et al. 2005. A Relatedness Analysis Approach for Regulation Comparison and E-Rulemaking Applications, Proceedings of the DG.O Meeting. 
[7] Morales, Oscar \& John Moses. 2006. eRulemaking's Federal Docket Management System, available at http://erulemaking.ucsur.pitt.edu/doc/Crossroads.pdf.

[8] Noveck, Beth. 2004. The Electronic Revolution in Rulemaking, Emory Law Review 53: 1 (2004).

[9] Schlosberg, David, et al., 2005. 'To Submit a Form or Not to Submit a Form, That Is the (Real) Question:’ Deliberation and Mass Participation in U.S. Regulatory Rulemaking, available at http://erulemaking.ucsur.pitt.edu/ doc/papers/SDEST_stanford_precon.pdf.

[10] Shane, Peter M. 2005. Turning GOLD into EPG: Lessons from Low-Tech Democratic Experimentalism for Electronic Rulemaking and Other Ventures in Cyberdemocracy, I/S: Journal of Law and Policy for the Information Society 1: 147.
[11] Shulman, Stuart W. et al., 2003., Electronic Rulemaking: A Public Participation Research Agenda for the Social Sciences, Social Science Computer Review 21: 1.

[12] Shulman, Stuart. 2004. The Internet Still Might (But Probably Won't) Change Everything, available at: http://erulemaking.ucsur.pitt.edu/doc/reports/erulemaking_final.pdf.

[13] Stowers, Genie. “The State of Federal Websites,” Price Waterhouse Coopers Endowment for the Business of Government (2002).

[14] West, Darrell. Digital Government (Princeton University Press 2005). 